\title{
The Indonesian Economy from the Colonial Extraction Period until the Post-New Order Period: A Review of Thee Kian Wie's Major Works
}

\author{
Maria Monica Wihardja ${ }^{\mathrm{a}, *}$, Siwage Dharma Negara ${ }^{\mathrm{b}, * *}$ \\ ${ }^{a}$ World Bank Office Jakarta \\ ${ }^{b}$ Indonesian Institute of Sciences (LIPI)
}

\begin{abstract}
This paper reviews some major works of Thee Kian Wie, one of Indonesia's most distinguished economic historians, that spans from the Colonial period until the post-New Order period. His works emphasize that economic history can guide future economic policy. Current problems in Indonesia were resulted from past policy failures. Indonesia needs to consistently embark on open economic policies, free itself from "colonial period mentality". Investment should be made in rebuilding crumbling infrastructure, improving the quality of health and education services, and addressing poor law enforcement. If current corruption persists, Indonesia could not hope to become a dynamic and prosperous country.
\end{abstract}

Keywords: Economic History; Colonial Period; Industrialization; Thee Kian Wie

\begin{abstract}
Abstrak
Tulisan ini menelaah beberapakarya besar Thee Kian Wie, salah satu sejarawan ekonomi paling terhormat di Indonesia, mulai dari periode penjajahan hingga periode pasca-Orde Baru. Karya Beliau menekankan bahwa sejarah ekonomi dapat memberikan arahan dalam perumusan kebijakan ekonomi mendatang. Permasalahan yang dihadapi Indonesia dewasa ini merupakan akibat kegagalan kebijakan masa Ialu. Indonesia perlu secara konsisten menerapkan kebijakan ekonomi terbuka, membebaskan diri dari "mentalitas periode penjajahan". Investasi perlu ditingkatkan untuk pembangunan kembali infrastruktur, peningkatan kualitas layanan kesehatan dan pendidikan, serta pembenahan penegakan hukum. Jika korupsi saat ini berlanjut, Indonesia tidak dapat berharap untuk menjadi negara yang dinamis dan sejahtera.
\end{abstract}

Kata kunci: Sejarah Ekonomi; Periode Kolonial; Industrialisasi; Thee Kian Wie

JEL classifications: N55, N65

\section{Introduction}

Indonesia's current economic performance is a resemblance of its long economic tradition since the colonial extraction period. Some similar characteristics can be found between the colonial economy with the current economic situation. One of clear evidences is the fact that Indonesia is still highly dependent on its abundant natural resources for its revenues. In 2012, commodity exports such as

* Corresponding Address: World Bank Office Jakarta, Indonesia Stock Exchange Building Tower 2, 12th Floor. Jl. Jenderal Sudirman Kav. 52-53 Jakarta, 12190. E-mail: mw ihardja@ worldbank. org.

**JI. Jend. Gatot Subroto No. 10, Jakarta Selatan 12710 Indonesia. E-mail: siwage@yahoo.com. palm oil, rubber, wood, coffee, and cacao made up around 55 percent of total main export products ${ }^{1}$

There are many factors constraining the Indonesian economy to industrialize and move up the value chain. Inconsistent, unclear and often overlapping government policies contribute to suboptimal economic performance. While at the same time, infrastructure and skill gaps are also impeding the industrial development, technological transfer and thus economic growth. For the Indonesian economy to move forward and to avoid the middle income trap, it needs to learn from history of its past policy failures and successes.

\footnotetext{
${ }^{1}$ Ministry of Trade, Statistik Perdagangan Luar Negeri Indonesia 2013.
} 
This paper reviews some major works of Thee Kian Wie, one of Indonesia's most distinguished economic historians, that spans from the Colonial period until the post-New Order period. His works, written in the 1980s until his passing in February 2014, should remind us about the importance of our economic history to give us guidance for future economic policy and strategy. His major works emphasize that the problems that Indonesia faces today were the results of past policy failures. In some of his works, for instance, Thee argued that Indonesia's relatively weak industrial development could partly be explained by its inconsistency in implementing the industrial policies during the oil boom and oil shock periods. Thee always concerned about 'half-heartedness' of the government of Indonesia to fully embrace the pro-competition policies. The government easily switched policies to trade or industry restriction policies especially on sectors like mining, energy, and infrastructures, signaling failures to stand tall on political pressures (Wihardja 2014).

The paper is organized as follows. The analysis section reviews on Thee's major works on the Indonesian economic history since the colonial extraction period until the new order period; Thee's important works on industrialization policies, including his reflections on East Asian Development strategy and technology transfer; and some of the lessons learned for Indonesia on past policy failures and successes on trade and industry. This section also reviews Thee's works on some social aspects of development including on equity, poverty and disparities of income distribution. The final section concludes and provides some policy recommendations.

\section{Analysis}

\subsection{Indonesian Economic History since the Colonial Extraction Period}

As one of Indonesia's most renown economic historians, Thee Kian Wie has produced some influential works on the Indonesian economic history, including "The Emergence of a National Economy: An Economic History of Indonesia, 1800-2000", published in 2002 and "Indonesia's Economy since Independence" published in 2012. His works went as far back as the first appearance of the Dutch in 1596. Thee's publications were voluminous, commencing with the publication of his Ph.D. dissertation from the University of Wisconsin.

In 2002, he published a collaborative volume on The Emergence of a National Economy with Howard Dick, Vincent J.H. Houben and J. Thomas Lindblad, in recognition of the lack of an up-to-date textbook on the Indonesian economic history. Four of his book chapters, making up a sequel of Indonesia's economic history starting from the arrival of the Dutch first voyages in the archipelago in the late sixteenth century to the Soeharto era, deserve special attention.

Thee's "Colonial extraction in the Indonesian archipelago - A long historical view" (Thee 2013a) is a paper that goes back as far as the late sixteenth century when the first voyages by the Dutch arrived in the archipelago. Correcting the perception that Indonesia was colonized by the Dutch for 300 years, as most of Indonesia's history textbooks would state, Thee made a point that unlike the Portuguese and Spanish, the Dutch were exclusively motivated by the wish to find trade opportunities, especially spices on the Moluccan islands, such as the highly-valued nutmeg. The paper continued with the evolution of the Dutch presence and policies in the Netherlands Indies.

First was the Dutch East India Company (VOC) that was established in 1602 to represent the combined interests of several Dutch trading companies. "The VOC enforced a bilateral monopoly on the spice trade in the Moluccas: a monopsony on the purchase of the spices in the Moluccas combined with a monopoly on the sale of these spices in the Dutch Republic." (p. 41) Four years after the French occupation of the Dutch Republic, the 'bleeding' VOC, partly due to corruption of its officials, was disbanded in 1799. During the French occupation in the Dutch Republic, Louis Napoleon sent Marshal Daendels as the new governor general who executed the construction of a major highway of around $1000 \mathrm{~km}$ connecting the Western and Eastern end of Java through corvée services in which resulted in the death of thousands of unpaid peasant workers. When the British took over in 1811, Raffles continued with Daendels' reforms in transforming VOC. After Napaleonic wars ended 
in 1815 , the Dutch resumed authority in Java. The Java War - the last big war between the Javanese and the Dutch until the 1940s - then broke in 1825 that lasted until 1930, when Prince Diponegoro was arrested.

Second was the Cultivation System that was introduced in 1830. It was believed that forced cultivation of export crops for the European market would offer the most effective remedy against structural deficits in both the Netherland Indies government and the Dutch Republic. The Cultivation System was proven to be "a stroke of fiscal genius" ( $p$. 45) whose proceeds were directly remitted to the Dutch treasury. During the period 1851-60, profits from the Netherland Indies accounted for as high as one-half of total national revenues. "Indeed, the profits from the Netherlands Indies were indispensible for servicing the high Dutch national debt and for maintaining balance in the state budget" (p. 48). However, famines broke in Demak and Grobogan in 1848 and $1849-50$ respectively as resources were being taken away from domestic food production in lieu of export including in times of crop failures. Almost one-fifth of the pre-1848 population in these regions died because of faminerelated illnesses. Thee noted that even a conservative Dutch historian would call this period as "one of the most shameful pages in the Dutch colonial history" (pp. 47-48). The Cultivation System was abolished in 1870, not because of the cruelty and the many deaths it caused, but primarily because private Dutch entrepreneurs wanted to invest in the colony themselves.

Third was the "liberal era" in 1870, when private capital was allowed to enter the colony freely. Not only did Dutch private entrepreneurs gain access to private investment, but also indigenous entrepreneurs. After 1880, private investment increased rapidly. Thee strongly argued that the increased use of Chinese middleman in the tax farm system at that time, such as to collect taxes from local population, had a long-term consequence that was "the strong anti-Chinese sentiment among the Javanese population which has persisted to the present day" (p. 52). The liberal reforms were perceived to be successful in supporting the expansion of the colonial economy, although there is little evidence that the liberal reforms led to a significant improvement in people's welfare in general.
Fourth was the Ethical policy that was introduced in the 1900 until the 1920s, primarily because the Dutch felt the obligation to take responsibility for the welfare of the Indonesian people for excessive exploitation in previous periods. The Ethical policy also resulted in the training programs for civil servants before they came to the Netherlands Indies. The highly trained officials were also "genuinely devoted to the cause of improving the welfare of the Indonesian people" (p. 53). However, the Ethical policy had failed to achieve anything that it was referred to as the "Doctrine of the Little Push" (p. 53). The welfare ideology of Ethical Policy simply contradicted the colonial ideology. The latter was mainly driven by economic and political motivations of the colonial government. As a result, no significant improvement on the welfare of the Indonesian people, in education, by 1930 s, only 7.4 per cent of adults were literate. By the early 1920s, the Ethical Policy had been abandoned.

Fifth was the period of the Great Depression in 1930s, the Japanese occupation in 1942 and finally, Indonesia's independence in 1945.

In the summary, Thee made an interesting point: "Institutions and practices of extraction, leading to regressive distribution of assets, income and wealth, have been sustained during the postcolonial era. ... The abuse of public resources by rent-seeking elites (including those during the Soeharto era), has been a constant factor in Indonesian history and the Dutch colonial rule set the example in its most extreme form." (p. 57).

It is clear from this paper, that Thee was never short of covering the welfare impacts of any policy or event in history in most of his writings. $\mathrm{He}$ also usually provided a balance argument on his analysis, for example, he noted the positive sides of the Dutch and the Japanese occupation, including investments in public goods and services.

In Anne Booth's Festschrift (Thee 2013b), Thee wrote a detailed account of Indonesia's economy during the Japanese occupation, starting from December 8, 1941, when the Dutch declared war on the Japanese, to Indonesia's independence on August 17,1945 . Unlike many of his writings, Thee addressed open-ended questions that he himself could only speculate on answering. For example, he asked, why the Netherlands declared war against Japan before the U.S. did? In this book chapter, Thee also corrected some common pub- 
lic perception that Indonesia was colonized by the Dutch for 300 years, while in fact there were only four ships that arrived and stayed in the Indonesian archipelago. "Indonesians even today say, that Indonesia was colonized by the Dutch for three hundred years, which historically is totally wrong. This statement would have implied that when Cornelis de Houtman landed in the port of Banten in 1596, he and his four ships swept over the entire Indonesian archipelago like a tsunami!" (p. 4).

In this paper, he acknowledged the role reversal of the U.S. relation with China and Japan, i.e. how the U.S. was used to be an ally of China (and not Japan), before China fell into the hand of Chairman Mao Zedong in 1949, when the U.S. foreign policy turned 180 degree. Thee also narrated how Japan, being desperate for imported oil embargoed by the U.S., Great Britain and the Dutch, decided to wage a war in South East Asia including Indonesia, instead of stopping the pyrrhic war against China. Like in his other writings, he portrayed the cruelty of the Japanese occupation, although, providing a balanced analysis, he argued that without it, "it would have taken a much longer time for Indonesia to become independent" (p. 12). Moreover, Thee noted that during the Japanese occupation, many Indonesians gained valuable experience and skills by occupying high positions in the bureaucracy, which were proven to be valuable when Indonesia became independent.

In Thomas Lindblad's Festschrift (Thee 2014), Thee portrayed a struggling Indonesia for a real independence from the Dutch in the post-1945 independence period, including from issues on the 15 puppet states, independence of West Papua and the huge debt Indonesia inherited from the Dutch Indies government. Thee also noted early economic advisors, such as Sumitro Djojohadikusumo, Sjafruddin Prawiranegara and Djuanda Kartawidjaja, as "pragmatic and certainly no less nationalistic than their detractors" (pp. 9$10)$. Thee described the resentment and unhappiness of the Indonesians over the continuing presence of the Dutch businesses, and soon the role of the military and the Chinese Indonesians in stateowned enterprises began when Dutch companies were taken over by trade unions in 1957 that were finally nationalized by 1959 . Thee argued that in order to divert attention from domestic turbulences at home, Soekarno launched "Ganyang Malaysia" (Crushed Malaysia) that soon led to the severing of relationship with the U.S. and its other Western AIlies and alignments with socialist countries as well as Indonesia's withdrawal from the United Nations after Malaysia was admitted as a non-permanent member of the Security Council. During this period, Soekarno closed itself from foreign aids, especially from the U.S., although it needed so much of these foreign aids amidst deteriorating economic condition at home. However, Soekarno put politic above economic considerations. Thee argued that the U.S. economic aid in the 1950s was primarily to improve the U.S. relationship with Indonesia, although Soekarno had little capacity and interests for this economic aid. Putting politics above economics, Soekarno's leadership eventually led to economic and political collapse in 1965.

Thee's book chapter in The Emergence of $\mathrm{A} \mathrm{Na}$ tional Economy (2004), "The Soeharto Era and After: Stability, Development and Crisis, 1966-2000" is one among his many other works to cover the Soeharto era. After the alleged coup of 30 September 1965, Soekarno reluctantly signed a decree, referred to as Supersemar, giving Army Commander Lieutenant General Soeharto the authority to restore order, which in effect giving him a transfer of executive power ${ }^{2}$. Soon after that, in 1968 , Soeharto was appointed as Indonesia's second President.

Thee noted that the difference between the Old Order and the New Order was not only in terms of political leadership but also their fundamental missions. While Soekarno developed "socialist economy a lá Indonesia" under a "guided democracy" (Thee 2009a), for the New Order, the fundamental mission was to boost economic development. Thee also wrote: "One of the proudest achievements of the New Order was its success in combining rapid growth with a sustained reduction in the incidence of absolute poverty." (p. 225). The major reason of this was because in the early period of the New Order under Soeharto was able to maintain political stability and macroeconomic stability. The stability could be achieved partly because Soeharto was assisted with competent technocratic economic advisers, such as Widjojo Nitisastro, Ali Wardhana, Mohammad Sadli, Subroto

\footnotetext{
${ }^{2}$ There are different stories about Soeharto's accession to Presidency because the letter, Supersemar, was never found, raising suspicions that Soekarno never signed such as a decree.
} 
and Emil Salim, whom Soeharto trusted and listened to. The incidence of absolute poverty decreased from 40 per cent in 1976 to 11 per cent in 1996. However, Thee was not short of noting the New Order's "corrupt" and "ruthless" (p. 241) political power in its later period.

During the early years of his Presidency, Soeharto appointed five economic advisors or professors, as his economic confidants, whom he met at a military school, Seskoad (the Army staff and Command School), where these five economists used to give lectures to Soeharto as a senior army officer. The five economists, often known as "the Berkeley mafia", were: Widjojo Nitisastro, Subroto, Emil Salim, Ali Wardhana, and Muhammad Sadli. This was also the school where the military prepared for their dual function (dwifungsi) and eventually built an alliance with the civilians, which in 1966 overthrew the Old Order.

Thee divided Soeharto's era into three phases ( $p$. 203). The first phase (1966-1973) was a period of "stabilization, rehabilitation, partial liberalization and economic recovery". The second phase (1973-1982) was a period of "oil booms, rapid economic growth and increasing government intervention". The third phase (1983-1996) was a period of "post-oil boom, deregulation, renewed liberalization and rapid export-led growth". For each phase, Thee's analysis brings a wealth of lessons learned from policy failures and successes.

One of the basic features that distinguished Soeharto's economic policies from those of Soekarno was an open economy. The hostile investment policy of Soekarno was reversed by enacting a new Foreign Direct Investment Law in 1967. Foreign direct investment immediately skyrocketed from $\$ 83$ million in 1967 to $\$ 271$ million in 1972. In 1972 , capital account transactions were also liberalized to move freely in and out of the country. Indonesia, through its 'balanced budget' law in 1967, which prohibited domestic financing through domestic debt and money creation, allowed foreign aids through Official Development Assistance (ODA) to finance domestic budget deficit. By 1990, Indonesia has become the largest aid-recipient country receiving around $\$ 1.8$ billion $^{3}$. "These official aids flow turned out to be crucial, as the implementation

\footnotetext{
${ }^{3}$ http: //data. worldbank. org/indicator/DT . ODA . ALLD. CD?page=4. Accessed on August 29th, 2014.
}

of the balanced budget law was crucially dependent on continued annual inflows of foreign aid." ( $p$. 205) As a result of fiscal and monetary disciplines, inflation declined from 636 per cent in 1966 to 9 per cent in 1970. Soeharto and his technocrats realized that new foreign aid and foreign investments were crucial to the survival of the new government, putting behind nationalist rhetoric. Over the period of 1967-1973, economic growth recovered to an impressive record, averaging over 7 per cent annually.

In the second episode of Soeharto's leadership, Indonesia experienced a windfall of oil revenues from two oil booms in 1973/1974 and in 1978/1979. The oil boom in the 1970s drove Indonesia to pursue one of the most inward-looking patterns of industrialization among the Asian developing countries. In the first 'easy' phase of import substitution, Indonesia imposed tariff and non-tariff protection including total import bans on some goods already assembled or manufactured in Indonesia, enabling locally made light consumer goods and consumer durables to replace imported products. In the late 1970s, Indonesia conducted the second 'easy' phase of import substitution, which involved 'deepening the industrial structure'. Thee noted that "the government's 'industrial deepening' plan" was "'one massive exercise in import substitution' without any reference to efficiency or exportability considerations." (p. 222). And moreover, "this industrial strategy was strongly supported by the government/ military bureaucracy, whose economic fortunes would be greatly advanced by the establishment and operation of new, large stateowned industries." (p. 222). Indonesia also imposed mandatory "deletion programs" (p. 223), under which intermediate goods were required to use progressively more of locally made parts and components. This hurt export-oriented firms, who required high-quality parts and components. This deletion program has never been successful. Indonesia still relies on imported parts and components. There are several reasons for failure of the deletion program, i.e. inadequate skills, lack of information and lack of discipline on the part of the government and most problematic is the program was prone to rent-seeking activities and vestedinterest groups.

In 1974, anti-Japanese riots broke during a state visit by Japanese prime minister Tanaka, in protests of the perceived "sell-out" (p. 208) of the 
economy to foreign capital and the perceived preferential treatment to ethnic Chinese entrepreneurs. Having succeeded in economic recovery, the government reversed its liberal, free-market policies in favour of more inward-looking and interventionist policies, supported by increased government revenues from oil taxes. From 1974, foreign direct investment could only enter the country in the form of joint venture with Pribumi owning a majority ownership. This resonated with the Benteng program (1950-1957) whose main goal was to build a strong Pribumi economic class vis-à-vis the ethnic Chinese entrepreneurs.

In mid-1970, Pertamina, the powerful state-owned company, defaulted on a short-term loan from a foreign bank. There was a big debate between the government under the supervision of the technocrats and Pertamina on the change in the production-sharing contracts and subsequent financial autonomy of Pertamina. In a separate book, Thee wrote that in times like the Pertamina crisis, Soeharto acted like "a responsible head of government", supporting the technocrats who were trying to safeguard the country's state revenues, instead of giving absolute protection to Pertamina (Thee 2003, p. 135).

After a decade of oil booms in the 1970s, Indonesia soon found itself running out of oil revenues with oil price dropped twice in 1982 and 1986. To move the economy away from its dependence on oil exports, Indonesia shifted from import-substitution to export-oriented industrial strategy. Not until 1986 when oil price fell more steeply than in 1982, did the government really push through trade reforms towards export promotions. Beside trade reforms, the government also deregulated foreign direct investment, by removing restrictions that had been re-introduced in 1974. The most significant liberalization of foreign direct investment was in 1994. As in many other writings, Thee often emphasized the interdependence between industrial, trade and investment policies. For example he noted that whether or not foreign direct investment in Indonesia is trade-oriented, referring to whether it promotes exports of finished products from the host country or promotes exports of parts and components from the home country (Thee 1984).

Despite the rapid growth in the late 1980s, Indonesia slowly moved from what Thee called a "developmental state" to a "predatory state" (Thee 2008a). Corruption, collusion and nepotism were rife. When non-oil manufactured exports began to slow down in the early 1990s, partly due to competition from low-labour-cost regional countries, putting pressures on the declining current account balance, B.J. Habibie who was then the powerful Minister of State for Research and Technology, pushed for costly high-technology industries, including his aircraft industry. But, without prudent policy that properly considered resource constraints, this ambitious project became more of a parasite. Deregulations in the financial sector in the late 1980s, but without enough enforcements of prudential regulations, also allowed rapid expansion of a weak banking system. People's dissatisfaction with 'corrupt' economic institutions was exacerbated by people's fear of repressive political regime. For many of the reasons above, the Indonesian economy became vulnerable to rupiah extreme depreciation, aggravated by un-hedged and maturity as well as currency mis-matched private sector debts. The speculative attacks in the financial and banking sectors soon spiraled down into an unprecedented economic crisis and political crisis that witnessed the fall of the 30-year of Soeharto leadership.

Thee made three important points in the analysis of the Soeharto era. First was the importance of 'good governance'. He wrote, "the only strong institution seemed to be President Soeharto himself, who was not a sustainable institution" (p. 241). Second was the two-edged sword of globalization. "The Asian crisis also showed that globalization may require institutions to change faster than they are able to" (Thee 2008a, p. 241). Last were "the growing disregards of economic analysis in policy formulation" with "the rise of interventionist policies resulted from accumulation of corrupt political power that eroded business competitiveness and rewarded rent-seeking policies" (Thee 2008a, p. 241). Thee also made a note on the environmental degradation and depletion of energy because of the high-growth economy and greed.

Furthermore, the perspective taken by Thee in his analysis on the colonial policies on Indonesian economy, is well described by Hill, Negara, and Wihardja (2014): "Thee's economic history work was generally positive rather than normative in tone. That is, he did not set out to condemn the colonial system beyond its obvious iniquities, nor did he engage with some of the grand debates, such 
as the 'colonial brain drain', or theories of imperialism. Rather, he sort to meticulously document and analyze the Dutch colonial economic system and its impacts on local commerce and living conditions".

\subsection{Industrialization Policy and East Asian Development Strategy}

Thee was a strong believer of the benefit of foreign direct investment. In several papers, he argued that Indonesia badly need more foreign direct investment in order to get the much needed capital, new technology and modern management methods and access to export markets. He consistently reminded the government of Indonesia for not continuing to rely on abundant natural resources and cheap labour, instead to seriously develop and upgrade the technological capabilities of the country's manufacturing sector (Thee 2008b).

In his paper, "Japanese Direct Investment in Indonesian Manufacturing" (Thee 1984), Thee argued that the Japanese investment in the early 1970s had been of the "import-substitution" rather than "export-orientation" type. It had been "antitrade oriented" (p. 95) in the sense that it did not promote exports from Japan of industrial raw materials, parts and components, nor did it promote exports of finished products from the host country. He argued that of the Japanese components and parts were "directly from explicit arrangements between the Japanese parent company and its Indonesian subsidiary commonly as a package deal" (p. 101). Not because of the Japanese comparative advantage in the supply of these inputs. Thee argued that although Japanese investment has been in labourintensive manufacturing in Indonesia, it may be said to have been potentially export-oriented. But, a survey showed that Japanese investors' decision to invest in Indonesia was the potential of the local market and not to export, because they saw opportunities to produce products that had been protected from imports. He argued that "Whether or not the Japanese direct investment in Indonesian manufacturing is trade-oriented or not depends on whether the country is pursuing a path of exportoriented industrialization or import-substituting industrialization." (p. 105).

In his other paper, "The Surge of Asian Newly
Industrialized Countries (NIC) Investment into Indonesia" (Thee 1991), Thee described the surge of export-oriented NIC investment in the 1980-1990s. There were pull and push factors for the surge. Some of the pull factors include: the steep drop in oil revenues in 1982 and 1986 forcing the government to shift from import-substitution strategy to export-oriented strategy. This resulted in the condition where exporters had been able to buy inputs from foreign and domestic suppliers at international prices and government supported by adopting an active exchange rate policy (Thee 1991). The government ensured that the exchange rate is competitive to support the growth of non-oil exports (Thee 1991).

The surge of investment in that period of 19801990 s, is also influenced by the external factors. Stated in Thee (1991): "There were also the push factors, including: the substantial appreciation of the NIC currencies and a rapid rise in wages of the NIC; the abolition of foreign exchange control by the Taiwanese government in 1986; the support from the Korean government to Korean private firms to invest in South East Asia; and the development of Batam with Singapore as an industrial estate to which Singapore's labour-intensive industries can relocate their operations".

Asian NIC (Korea, Taiwan, Singapore and Hong Kong) accounted for $58 \%$ of new investment projects approved and 84 per cent of Asian NIC projects approved during 1990 were exportoriented (compared to 59 per cent of Japanese projects approved). Among Asian NIC investment projects mostly were Korean and Taiwanese that were export-oriented, partly because they came later only to exploit a low-cost export base and long relation they have developed with buyers from the developed countries. Other features of Asian NIC investments, include: (1) large operations in terms of volume of outputs and number of workers, (2) labour-intensive nature - 64 per cent of Korean projects and 43 per cent of Taiwanese projects were located in highly labour-intensive projects, (3) mostly 'low-technology' industries, but capital and technology-intensive path of industrialization in Korea and Taiwan resulted in a few projects in highly intensive technology industries in Indonesia.

"The orderly transfer of technology 4 of NIC projects

${ }^{4}$ Thee (2001) defined technology transfer as a process "that 
to Indonesian owned and controlled operations may be one of the major contributions of NIC investment to Indonesia. Acquiring advanced technologies through technical licensing agreements would certainly avoid the politically sensitive problems of 'foreign domination' over the economy which has often bedeviled the making of economic policy in Indonesia." (pp. 86-87)

To achieve rapid and sustained economic growth, Thee argued that Indonesia should not only focus on agricultural development but also should seriously support its industrial development. Based on empirical findings, no developing country would be able to transform itself into a developed country if it were to focus only on agricultural development, while neglecting or deferring industrial development. To improve the competitiveness of Indonesia's manufacturing sector, Thee recommended (many times) that the Indonesian government must stop providing the industry with preferential treatment (such as the wood products, mining, palm oil). The government should also force the industry to adhere to the country's strict environmental obligations.

A big player in Indonesia's economic development is the Micro, Small, Medium and Large enterprises (MSME). Thee argues that Indonesia's 'hollow middle' resulted in assembling/ intermediate industry in Indonesia to rely on expensive imported goods. In his book chapter, "SME Policies in Three East Asian Nations and Their Relevance for Indonesia" (Thee 2004, p. 283), Thee drew experiences from SME in Japan, South Korea and Taiwan. Thee argues that the Japanese experiences show that government loans are essential funding sources for newly established SME, most of whom are sub-contractors to big industries. Efficiency in SME in manufacturing industry in Japan is the main factor in highly competitive manufacturing industry in Japan, such as machinery, electricity, and cars.

In the case of South Korea, the government implemented selective intervention by limiting FDI

involves the transfer of skills and technical know-how as well as the transfer of machinery and other capital equipment (embodied technology). Technology transfer can take place through various channels such as foreign direct investment (FDI), technical licensing agreements, imports of capital goods, foreign education and training, turnkey projects, technical consultancies, copying or 'reverse engineering', and participation in world trade. from multinational companies in strategic industries and protecting the Chaebol - Korean conglomerates. Manufacturing industry was dominated by these Chaebol that were given incentives and leniencies. However, competition was encouraged among these Chaebol and the government imposed standard performance requirement, such as high export performance. Technological diffusion was encouraged by developing a network of subcontractors who were mostly SME. The South Korean government issued a law prohibiting components and sub-components to be in-house manufactured, but must be purchased from SME instead. During that period of time, SME contributed 35-40 per cent of total export in the country, although 2 per cent of total firms namely the Chaebol produced 62 per cent of GDP. In fact, productivity growth of SME was higher than big companies since they used the same level of technology as big companies, partly because they were more agile in adopting new technology.

In the case of Taiwan, Thee emphasized that physical infrastructure in small villages and access to ports support SME not only in agglomerated cities but also rural areas. This is par to the reason that growth has been more equitable (than say, South Korea) and growths in agriculture and manufacturing were more balanced. There were no barriers to entry and the Chinese "self-entrepreneurial" aspiration encouraged Taiwanese to open their own businesses. SME were export-oriented and had high international competitiveness. SME were important sources of exports by mid-1980s. During that period, SME accounted for 70 per cent of total employment and 55 per cent of GDP and 62 per cent of export revenues.

\subsection{Lessons Learned For Indonesia on Industrial Policy}

Indonesia recently passed Trade Law (Law No. 7, 2014) and Industry Law (Law No. 3, 2014). Amidst the end of commodity boom (2003-2012) and a widening current account deficit, Indonesia has moved towards more inward-looking and protective trade and industrial policies in recent years. Supply-side constraints limit export competitiveness and import-substitution seems to be the only 'quick' solution to narrow the widening current account deficit. In fact, these new com- 
plementary 'twin sisters' laws are just confirmations of Indonesia's more inward-looking trade policy and protective industrial policy for the past two years, as evident in the words of the government: "The Trade Law affirms our standpoint that Indonesia does not fully embrace free trade," 5 and "with the implementation of the newly approved Industrial Law, Indonesia will have a strong legal base to promote import substitution as well as downstream industries in efforts to reduce the manufacturing sector's heavy reliance on imports of components and machinery." ${ }^{6}$ Although Indonesia is among the ASEAN6 countries (outside Cambodia, Laos, Myanmar and Vietnam) with Common Effective Preferential Tariffs virtually zero, Indonesia's Core Non-Tariff Measures Restrictiveness Index in 2009 is highest among ASEAN member states ${ }^{7}$. Hence, we cannot argue that the Trade Law is a response to a trade policy that is too liberal.

Thee had warned that: "Import-substituting industrialization, if pushed ahead behind highly protectionist walls, is economically inefficient. It leads to serious distortions in the economy which are extremely difficult to correct once they are built into the economic structure of a country. For not only are physical structures or complexes of production established, but more importantly from the political economy view point, vested interests favouring the status quo which are supported by political power holders become practically impossible to dislodge, even when the high economic costs of these arrangements become evident." (Thee 1984, p.105)

Experiences from South Korea, Hong Kong, Taiwan and Singapore showed that some degrees of "selective government intervention" to build industrial capacity at home had succeeded in putting these countries to become highly industrialized and high-income countries. However, Thee argues that what often happens in many developing countries, including Indonesia, with their importsubstitution industries, is that, interventions often times are not created to fix specific market failures. They are not preceded by concrete costs and

\footnotetext{
${ }^{5}$ Source: http://www.theaustralian.com.au/business / jakarta-freely-admits-it-is-shielding-local-stakeholders / story-e6frg8zx-1226830971710\#.

${ }^{6}$ Source: http://ww.thejakartapost.com/news/2014/ 02/07/ri-focus - import-substitution-industry.html.

${ }^{7}$ Source: http://www .eria.org/Mid-Term\%20Review\% 20 of $\% 20$ the $\% 20$ Implementation $\% 20$ of $\% 20$ AEC $\% 20 B 1$ ue $\%$ 20Print-Executive\%20Summary .pdf, p. 11 and 24.
}

benefits analyses and understanding of the barriers that inhibit efficient industrialization in the first place. Furthermore, these interventions are not conducted as they are supposed to be conducted and instead influenced heavily by pressures from vested interest groups. Therefore, selective government interventions in developing countries often times adversely create rent-seeking activities, which from the perspective of citizens' interests are not productive.

In other words, the success of selective government intervention is not without a condition. Drawing lessons learned for Indonesia on trade and industrial policies, as some of Thee's writings suggest include the following conditions.

The first is reciprocal-based intervention, which means that credits to some selected industries or firms are given only if accompanied by performance standards (Thee 2004, p. 299). For example, in the case of South Korea, governmentsupported Chaebols were imposed a high discipline to reach certain high export capacity in order to reach international competitiveness standard. Therefore, there must be some underlying implicit or explicit contracts between the government and the private sector in terms of certainties of political imperatives (including regulatory certainties) by the government on the one hand, and quality assurances by the private sector on the other hand. Hill and Aswicahyono (2014) suggest that, in any form of industrial intervention, there must be some market test standards, performance requirement and conditionality imposed on the 'winners'.

The second is "market-conforming intervention", which means that government intervention does not mean reducing firm competition, but on the contrary, it must support firm competition to maintain competitiveness of the selected industries (Thee 2004, pp. 268-269). Protecting inefficient firms from competition will put Indonesia in a highcost economy. In the case of South Korea, during the era of planned and directed industrial policy in favor of the Chaebols, the South Korean government supported at least two big Chaebols in every sector or industry it developed (Thee 2004, p. 299). Similar efforts to encourage domestic competition happened in Japan.

The third is institutionally-supported intervention. Government intervention must be supported by sound regulatory processes and sound institutions. 
Similarly important is what Hill and Aswicahyono (2014) call, "a convincing case that the Indonesian bureaucracy has the specialized knowledge of markets and technology, superior to that of major MNEs, to be able to make such a decision (of the form of intervention)." (p. 24).

The fourth is that in order to reach an economywide competitiveness, building one or two productive sectors is not enough. What is really needed is diffusion or structural change including technological diffusion from the most productive sectors in the economy to the rest of the economy. If Indonesia is to depend only on its comparative advantages, namely natural resources and resourcebased industries, it may never become a competitive economy-wide without a substantial structural change. In the case of South Korea, technological diffusion from the Chaebols to SME was done by issuing many regulations to support SME as subcontractors to the Chaebols, among which was by issuing a law restricting Chaebols to have in-house manufacture for their parts and components (Thee 2004, p. 299).

The fifth is that selective intervention is not a substitute for more "neutral" or "functional" intervention, such as infrastructure, education, research and technological development, and trade facilitation to ensure skill development and productivity (Thee 2004, p. 264). Increasing innovation and technological development are important to compete in the global market. Eventually, Indonesia's domestic value-added must not only come from natural resources, which are not sustainable in the long run, but also from creativity and innovation. In the case of South Korea, Singapore, Taiwan, and Hong Kong, the targeted upgrading of their industrial structure was consistent with changes in the soft and hard infrastructures, which were the results of deliberate investment in those sectors including skills, physical infrastructure and institutions. Their selective interventions also consisted of assisting firms to be capable of imitating and licensing foreign technologies, and making sure that they had accesses to the right skills and infrastructure.

The sixth is that macroeconomic fundamental must be sound. This is what we learned in the midst of the Asian Financial Crisis in 1997-1998, in which without a sound macroeconomic fundamental, the government quickly runs out its resources and pub- lic support on its highly protected high-tech industries.

The seventh is that trade and investment policies cannot be too restrictive in order to allow some degrees of external competition and foreign investment in some key areas. Some degrees of external competition is important for encouraging some local manufacturers to improve their capacity and to upgrade their product quality. And foreign direct investment remains important to get the much needed capital, new technology and modern management methods and access to export markets.

The eighth, and perhaps most importantly, is that the decision to intervene in costly industrial policy is really to address some sort of market failures that impede Indonesia's lack of competitiveness. Hill and Aswicahyono (2014) correctly argue that if Indonesia's lack of competitiveness is not the result of some sort of market failure or technological barriers, but due to high-cost domestic economy, inadequate education system, complex regulations and domestically-imposed barriers to international technology transfer, then the solution should be addressing the root causes and not embarking in some costly industrial policy.

\subsection{Social Aspect of the Development Policy}

Thee has also produced some important works on poverty and inequality. In 1981, he produced his essays collection on equity, poverty and disparity of income distribution published by Sinar Harapan. He believed that sustaining rapid economic growth is necessary to eliminate poverty in Indonesia. And he added that the economic growth should be complemented with economic empowerment of the poor through the promotion of small-scale and cottage industry in rural areas. He argued for cutting the bureaucratic procedures, red-tape, and addressing the disproportionate economic power which certain groups enjoyed. Thee strongly believed that Indonesia should seriously address the ever widening economic gap between the more prosperous ethnic Chinese Indonesians and the pribumi (indigenous) Indonesian majority and the wide development gap between Java and nonJava.

Thee's more contemporary works in the Post- 
Soeharto era mostly focus on development challenges and recent updates ${ }^{8}$. He often wrote about corruption, poverty and inequality as well as environmental degradation. In his 2013 short paper, Thee laid out four development challenges: combatting pervasive corruption; overcoming critical constraints to reducing poverty, inequality and unemployment; the dilapidated physical infrastructure; and the rapid decline of non-renewable natural resources at current rates of exploitation.

Thee believed that competition is important for industries to be competitive and efficient. However, he also acknowledged that some sort of government intervention is needed in the mid of market failures (Thee 2009b). He gave an example that even the most liberal country like the US still conducts some sort of government interventions. $\mathrm{He}$ warned that many developing countries wrongly applied state intervention (statism) characterized by dominant state control to capital, production factors, and distribution of resources. And as a result created government failures due to an inefficient allocation of goods and resources than that would occur without government intervention. A case in point was government's support in costly hightechnology industries, such as national car and aircraft. Often, government colludes with certain groups in society so only some exclusive groups received special treatment/facilities and economic resources were centered among these small number of groups.

Thee argued that the government should play a role as 'wasit yang adil dan netral' (fair and neutral referee) to all groups. For example, although Thee was critical of the Soeharto's later administration, he praised Soeharto when he supported the technocrats instead of giving absolute protection to Pertamina, during the Pertamina crisis in 1975. "Soeharto was both the head of the government and the Supreme Commander of the Armed Forces. However, in times such as the Pertamina crisis he acted like a responsible head of government." (Thee 2003, p. 135). In other words, the government should not let their policies being hijacked by small group of people (elite captured) for their own interests. In a resource rich country like Indonesia, Thee warned against 'predatory state', in which corruption related to resource rents was

\footnotetext{
${ }^{8}$ Various East Asia Forum articles (www. eastasiaforum. org).
}

very prone to reduce the efficiency of policy and administration.

\section{Conclusion}

Thee's major works had taught us that Indonesia needs to consistently embark on open economic policies. It needs to free itself from "colonial period mentality". Indonesia in its present time was hardly any different with Indonesia during the colonial period with extractive institutions, relying mostly on natural resources for much their revenues. For many years the country's industrial development plan has never been successful due to the tendency to pursue 'protectionist' policy without any reference to efficiency or competitiveness considerations. Indonesia has been trying to adopt selective interventions to support its local manufacturing industries. However, these selective interventions are prone to capture by vested interests. The root cause of the problem lies in the missing abovementioned conditions, including reciprocalbased, market-conforming and institutional-based interventions, as well as inadequate "neutral or functional" interventions to provide basic infrastructure and skills.

Thee's works clearly show a poor record of Indonesia's "industrial deepening" plan, which was "one massive exercise in import substitution" (Dick et al., p. 222). According to Thee, the Indonesian government and its people should engage in an informed and healthy debate about the many economic challenges facing the country. He realized that Indonesia is somehow 'allergic' to market competition partly due to their historical experiences with the Old Order government. During Soekarno era, he campaigned against western influences. Liberalism became political propaganda to fight western influence. Thee believed that it is important to educate people about market competition, to understand and to deal with its consequences. The government interferes to correct market failures. Though empirical studies also often shows interventions do not lead to its premises, and instead resulted to "government failures". The working of policies are important to understand of how tackling the failures in the first place ${ }^{9}$.

\footnotetext{
$9_{\text {http: }} / /$ asia.pacific.aw.edu
} 
Finally, Thee had reminded us that Indonesia needs to invest much more in rebuilding its crumbling infrastructure and improve the quality of health and education services. At the same time, he believed that Indonesia needs to improve law enforcement, governance and institutions capacity, particularly its bureaucracy, legal and judicial system. With its current level of corruption, Thee had warned that Indonesia could not hope to become a dynamic and prosperous country.

\section{References}

[1] Dick, H, Houben, VJH, Lindblad, JT \& Thee, KW 2002 , The Emergence of a National Economy: An Economic History of Indonesia, 1800-2000, Allen \& Unwin, Sydney.

[2] Hill, H \& Aswicahyono, H 2014, Indonesia's Medium Term Development Plan: Background Study on Competitiveness, draft report prepared for the Asian Development Bank, Jakarta Office, March.

[3] Hill, H \& Thee, KW (eds) 1998, Indonesia's Technological Challenge, Institute of Southeast Asian Studies, Singapore.

[4] Hill, H, Negara, SD \& Wihardja, MM 2014, 'In Memoriam: Thee Kian Wie: Dedicated Scholar and Public Intellectual'. Bulletin of Indonesian Economic Studies, vol. 50, no. 2, pp. 277-287.

[5] Thee, KW 1981, Pemerataan, Kemiskinan, Ketimpangan: Beberapa Masalah Pertumbuhan Ekonomi - Kumpulan Esei (Equity, Poverty, and Disparities Some Problems of Economic Growth), Sinar Harapan, Jakarta.

[6] Thee, KW 1984, 'Japanese Direct Investment in Indonesian Manufacturing', Bulletin of Indonesian Economic Studies, vol. XX, no. 2, pp. 90-106.

[7] Thee, KW 1988, Industrialisasi Indonesia: Analisis dan Catatan Kritis (Indonesian Industrialisation: Analysis and Critical Notes), Sinar Harapan, Jakarta.

[8] Thee, KW 1991, 'The Surge of Asian NIC Investment into Indonesia', Bulletin of Indonesian Economic Studies, vol. 27, no. 3, pp. 55-88.

[9] Thee, KW 1994, Industrialisasi Indonesia: Beberapa Kajian (Studies on Indonesia's Industrialisation), LP3ES, Jakarta.

[10] Thee, KW 1994, Explorations in Indonesian Economic History, Lembaga Penerbit Fakultas Ekonomi Universitas Indonesia.

[11] Thee, KW 2001, Channels of international technology transfer in Indonesia: A brief survey, ICSEAD Working Paper Series 2001-31. Available from: <http://www.agi . or.jp/user03/828_174_20110621144741.pdf>.

[12] Thee, KW (ed) 2003, Recollections: The Indonesian Economy, 1950s-1990s, Institute of Southeast Asian Studies, Singapore.

[13] Thee, KW 2004, Pembangunan, Kebebasan, dan "Mukjizat" Order Baru, Kompas - Freedom Institute Kedutaan Besar Denmark, Jakarta.

[14] Thee, KW 2008a, 'Indonesia's Economic Development During and After the Soeharto Era: Achievements and Failings'. A paper presented at the International Workshop for the Stocktaking Work on 'Asian Experiences of
Economic Development and Their Policy Implications for Africa', organized by JICA and JBIC, Tokyo, February 56, 2008.

[15] Thee, KW 2008b, 'Indonesia's Industrial Policies and Development since Independence'. Paper presented at Center for Southeast Asian Studies, Kyoto University.

[16] Thee, KW 2009a, 'Indonesia's Two Deep Economic Crises: The Mid-1960s and the Late 1990s', The Journal of the Asia-Pacific Economy, vol. 14, no. 12, pp. 49-60.

[17] Thee, KW 2009b, 'Neolib, Neoliberalisme, Apa Itu?', Kompas 26 May 2009.

[18] Thee, KW 2012, Indonesia's Economy Since Independence, Institute of Southeast Asian Studies, Singapore.

[19] Thee, KW 2013a, 'Colonial Extraction in the Indonesian Archipelago: A Long Historical View, Chapter 2', in Colonial Exploitation and Economic Development: The Belgian Congo and the Netherland Indies compared, eds E Frankema \& $\mathrm{F}$ Buelens, Routledge.

[20] Thee, KW 2013b, 'The Indonesian Economy During the Japanese Occupation', Jurnal Masyarakat Indonesia, vol. 39, no. 2, pp. 327-340.

[21] Thee, KW (forthcoming) 2014, The Indonesian Economy During the 1950s and Early 1960s and America's Proposal for Economic Aid.

[22] Wihardja, MM 2014, 'Looking at Thee Kian Wie', The Jakarta Post 23 June. 